\title{
ICTS AND EDUCATIONAL DEVELOPMENT: THE UTILIZATION OF MOBILE PHONES IN DISTANCE EDUCATION IN NIGERIA
}

\author{
Fatima Shehu KABIR \\ ICT Directorate, Kaduna State University \\ Kaduna, Nigeria \\ Abdullahi Tukur KADAGE \\ Department of Curriculum Studies and Educational Technology \\ Usmanu Danfodio University \\ Sokoto, Nigeria
}

\begin{abstract}
The demand for education in Africa has been on the increase. Thus, there is the need to identify more affordable ways of improving access to learning. For many decades, Open and Distance Education mediated by ICTs has been used to improve access to education. But in developing countries ICTS have been full of challenges of cost, and lack of appropriate infrastructure creating the notion of "digital divide". At the same time, we are now witnessing an unprecedented explosion in the number of mobile telephones globally, and in Nigeria. This technology, which is arguably the commonest means of communication, could play a pivotal role in extending the possibilities for teaching, learning, and research in distance educational institutions. Numerous studies have shown success stories of mobile learning in the developed world. This paper makes a case for implementing mobile learning in Nigeria by showing a number of successful Mobile Learning initiatives. The study also identified challenges that need to be addressed in order to sustain and succeed in the implementation of mobile learning in Nigeria.
\end{abstract}

Keywords: Mobile devices, distance education, open and distance learning (ODL), mobile learning, learning technologies.

\section{INTRODUCTION}

Distance Education has become one of the most rapidly growing fields of education and training. According to UNESCO (2002), it is fast becoming an accepted and indispensable part of the mainstream of educational systems in both developed and developing countries. The goals of distance education, as an alternative to conventional education, have been to offer degree granting programs, to battle illiteracy in developing countries, to provide training opportunities for economic growth, and to offer curriculum enrichment in non-traditional educational settings (Al-Fahad, 2009).

Distance Education is synonymous to technology: from print (correspondence systems), to Educational Radio and Television systems, to multimedia systems and then Internet based systems. Al-Fahad (2009) added that Distance Education relies heavily on technologies that include: Print, broadcast radio, broadcast television, computer conferencing, electronic mail, interactive video, satellite telecommunication and multimedia computer technology in order 
to promote student-teacher interaction and provide necessary feedback to the learner at a distance. Literature has however pointed to the persistent challenge of lack of infrastructural development in sub Saharan Africa (Yusuf, 2005; Olulobe, 2007; Kwache, 2007; Olakulehin, 2010; Ofulue, 2011), which impedes the use of appropriate technology to advance Distance Education.

According to (Osang, Ngole, \& Tsuma, 2013) the availability of new technologies which has opened up developing economies to the world market, has done little to help deprived groups gain access to educational opportunities. The infrastructural deficit associated with the region as well as the level of illiteracy poses great danger to the educational and general development of the continent. (Perraton, 2007; Osang, 2012) suggests the integration and use of information and communications technology (ICT) and open and distance learning (ODL) as a panacea. Surely, the integration of e-learning strategies into ODL is a step in the right direction. However, these strategies have not sufficiently broadened access to education especially to the rural dwellers in Nigeria. Kadage (2013) aptly stated that Educators and Planners are now discovering that anticipated benefits of the use of technology in distance learning instruction are not automatic or assured and this has often led to frustration and waste. He added that this reinforces the continued reliance of distance learning system on print material and broadcast technologies in developing countries and thus creates an IT access gap which is contributing to the widening 'digital divide' between haves and haves not in these countries.

Valk, Rashid \& Elder (2010) however posited that of the many different forms of ICTs, mobile phones are thought, for several reasons, to be a particularly suitable tool for advancing education in developing regions. Keegan (2005) stated that because of the lack of infrastructure for ICT (cabling for Internet and telecom) in certain areas in Africa, the growth of wireless infrastructure is enormous - even more rapid than in many first world countries. For Keegan (2005), using the mobile phone for learning is particularly suited to Distance Education because, "if serving the mobile learners is the focus of $M$ Learning, then D.E institutions have always been doing this---serving learners anytime, anywhere". Mobile technologies, which include hand held computers, Personal Digital Assistants, mobile phones, lap tops, and i-Phones, are all part of the emerging information revolution taking place worldwide. People need not work with large computers on desk tops, or made to carry laptops searching for wired internet connection. According to Bradford (2010), knowledge and learning is now literally at a person's fingertips via the mobile phone, and that several decades ago, when the nontraditional student began impacting higher education, distance education, asynchronous education and open or virtual learning emerged as a way to continually educate students.Keegan (2005) stated that: "one and a half billion people, all over the world, are walking around with powerful computers in their pockets and purses but they often don't realize it, because they call it something else.... today's high-end cell phones have the computing power of the mid-1990's PC, while consuming only one one-hundredth of its energy". Statistics, as indicated below, have established the exponential growth of mobile phones in sub Saharan Africa, even surpassing the figures in some developed countries. This is indeed a pointer to the important role mobile phones are expected to play in educational delivery in Nigeria. For example,

$>$ Nigeria and South Africa, are Africa's leading mobile telephony powerhouses, accounting for $45 \%$ of the continent's GSM industry (Nwaugwu \& Odetumibi, 2010).

$>$ "Nigeria, has overtaken South Africa to become the continent's largest mobile market with now close to 100 million subscribers, with market penetration at around 60\% in early 2012 (World Bank, 2013). 
$>\quad$ Nigeria is the largest mobile market in Africa and tenth largest in the world, though with low PC and fixed line penetration (Daily Trust, $17^{\text {th }}$ Nov 2014).

$>$ Total GSM subscribers in Nigeria stands at a total of 121,271,218 as at September 2013 (www.ncc.org).

$>$ Nigerians watch video on YouTube 4 billion hours every month (Daily Trust, 17th Nov 2014).

"Today wherever one looks, evidence of mobile penetration is irrefutable; cell phones, PDAs, MP3 players, portable game devices, handhelds, tablets, and laptops abound. No demographic is immune from this phenomenon. From toddlers to seniors, people are increasingly connected and are digitally communicating with each other in ways that would have been impossible only a few years ago" (Osang, Ngole, \& Tsuma, 2013)

\section{The Concept of Distance Education}

According to UNESCO (2002), the concept of distance education as a way of "opening" up education can be directly traced to an American visionary, Charles Wedemeyer. Wedemeyer realized that conventional face-to-face instruction would not be able to attain the vision of providing access to education for all, unless the barriers of time and space associated with face-to-face teaching are removed. Thus he popularized the concept "distance education", earlier called "independent study," and defined it as "a form of study that encompasses several teaching-learning arrangements in which teachers and learners carry out their essential tasks and responsibilities apart from one another, communicating in a variety of ways"(p. 2114).

Distance Education has traditionally been defined as instruction through print or electronic communication media to persons engaged in planned learning in a place or time different from that of the instructor or instructors. Yusuf (2006) echoes Holmberg's definition of distance education as:

"The various forms of teaching and learning at all levels which are not under the continuous, immediate supervision of tutors present with their students in lecture rooms or in the same premises but which nevertheless benefit from the planning, guidance and tuition of the staff of the tutorial organization" (p.1).

The traditional definition of distance education is slowly being eroded as new technological developments challenge educators to re-conceptualize the idea of schooling and lifelong learning. At the same time, interest in the unlimited possibilities of individualized distance learning is growing with the development of each new communication technology. Distance education has experienced dramatic growth both nationally and internationally since the early 1980's (Al-Fahad, 2009). Al-Fahad (2009) added that D.E has evolved from early correspondence education using primarily print based materials into a worldwide movement using various technologies. The goals of distance education, as an alternative to traditional education, have been to offer degree granting programs, to battle illiteracy in developing countries, to provide training opportunities for economic growth, and to offer curriculum enrichment in non-traditional educational settings. But in Nigeria there is still lack of these technologies.

On the global scene however, recent developments in interactive multimedia technologies offer a lot of promise to facilitate "individualized" and "collaborative" learning, and are blurring the distinctions between distance and traditional education. These technologies also have the capability of creating new environment for learning such as "virtual communities". 


\section{THE SIGNIFICANCE OF MOBILE LEARNING}

Multi mobile services have the potential to improve the educational environment in substantial ways. That we've ignored this potential for 10 years, and continue to ignore it today, is a blind spot we simply must correct. A billion mobile phones will be sold this year. A billion. This isn't a case of handwriting on the wall - this is a case of a revolution having occurred while we weren't looking. The information appliance of the future isn't in the future anymore; it's here today, in astonishing numbers. All of your students, and all of your prospective students, own one of these appliances. (Bradford, 2010)

Mobile technologies include portable and personal handheld devices, such as laptops, personal digital assistants (PDA), smart phones and mobile phones. Trifonova et al (2006) referred to mobile device as any device that is small, autonomous, and unobtrusive enough to accompany people in their life. For UNESCOIITE (2010), mobile learning is a form of learning that takes advantage of learning opportunities offered by mobile technologies, and that this happens when learners are not at a fixed, predetermined location. UNESCOIITE (2010) further stated that Mobile learning enables learners connect to learning from different locations and further emphasizes the integration of learning with life and work, so that education is no longer seen as a separate activity that has to take place in a school, university or other establishment.

Bradford (2010) cited a comprehensive definition of $\mathbf{m}$-Learning as "Learning that might take place independent of location and made possible through the use of mobile devices". She stated the characteristics of Mobile learning as:

$>$ ubiquitous-anywhere, anytime access;

$>\quad$ bite sized-components are relatively short in duration;

$>$ on-demand-always on' to deliver content at the point of need;

$>$ blended with other technologies-mobile technology is not the primary delivery platform;

$>$ can be collaborative-most mobile devices facilitate communication;

$>$ can be location dependent but does not have to be.

Peters (2007) stated that, mobile technologies can significantly reduce people's dependence on fixed locations, and thus have the potential to revolutionize the way people work and learn. According to Suki and Suki (2009), mobile devices are educationally interesting because they offer several communications channels on one device, cheaper, have comparable functionality with desktops or laptops, and also provide wireless access to educational materials. The ubiquitous feature of mobile devices which distinguish them from other learning tools has made mobile learning to be increasingly recognized in educational institutions.

Traxler (2007) made his categorization of mobile learning in to: Technology-driven mobile learning; Miniature but portable e-learning; Connected classroom learning; Informal, personalized, situated mobile learning; Mobile training or performance support; Remote, rural or development mobile learning. According to Traxler (2007), Mobile Learning in Africa is based on the last category only. The last category, remote or rural mobile learning means that technologies are used to overcome environmental and infrastructural challenges to deliver and support education where "conventional" e-learning technologies would fail (Traxler, 2007). 
According to UNESCOIITE (2010), Mobile learning has the following attributes:

$>$ Classroom dynamics: Mobile learning provides new means of communication and collaboration, and a way to connect classroom learning with learning elsewhere, the journey home and learning between lessons.

$>$ Connecting remote learners: Providing distributed learners with opportunities to exchange information, ask questions, and practice new skills in situ.

$>$ Learners as knowledge producers: When learners are commenting, discussing, or creating and sharing digital resources, the teacher's traditional authority function shifts towards a more collaborative or mentoring role. Learner-generated content represents a significant pedagogical resource and a shift towards authentic learning.

$>$ Experience capture: In work settings, recording and note-taking is facilitated, as part of collecting evidence of learning, or as a way to combine formal and informal learning.

$>\quad$ Lifelong learning: Over time, students become more able to take responsibility and the habits of lifelong learning can take root. This is facilitated by mobile access to social networks that can support a person's learning goals and career development over a lifetime (UNESCOIITE, 2010).

\section{THE UTILISATION OF MOBILE PHONE IN DISTANCE EDUCATION IN NIGERIA}

"Estimates put mobile subscriptions at more than 6 billion globally, with at least 75\% of these being in developing countries. Nearly 2.5 billion of the world's population can now access the Internet, a third doing so through mobile devices alone". (Ally and Tsinakos, 2014)

Indeed today, mobile phones are the most prevalent ICT in the developing world, and the penetration rate is rising rapidly. For example, in Asia, mobile penetration has doubled within a short span of time; in 2001, average penetration was 19.7 per 100 inhabitants while in 2005 the penetration rate rose to 40.9. Adedoja et al (2013) stated that mobile phone penetration in Africa is high, and mobile devices such as phones and PDAs (personal digital assistants) are available at much lower prices than desktop computers and therefore offer a less expensive means of communication. In South Africa there are 8 times more cell phones than computers, while in Nigeria 58.5 per cent of Nigerians in the rural population now have access to mobile phones (Nigerian Bureau of statistics, 2011), and pervasive evidence of mobile penetration and adoption is irrefutable as cell phones, PDAs, MP3 players, portable game devices and lap tops are increasingly being used in ways that would have been impossible to imagine only a few years ago (Adedoja, Adelore, Egbokhare, \& Oluleye, 2013).

The Mobile phone has been proposed by several researchers as the most suitable device to promote mobile learning (Muckos, Dawson, Edel-Malizia, Shaffer-Swaggerty, 2011; Makoe, 2012; Suki and Suki, 2010; Osang, F.B, Tsuma C., Ngole J., 2013). According to Suki and Suki (2010), the mobility and ubiquity of mobile phone makes it a very suitable medium for learning. Also Makoe et al (2012) stated that in distance education, lack of contact and limited feedback from lecturers is of great concern for distance learners. This leads to lack of confidence to learn independently and as a result distance learners have trouble in selfevaluation. Hence the mobile phone can thus be used as for communication between the instructors and distance learners, thus facilitating interaction through synchronous and asynchronous learning (Makoe et al, 2012). Distance learners could access library catalogues from home or on the road and they download course materials from anywhere beyond the campus. With the mobile phone, students could be encouraged to use social networks such as MXit, WhatsApp, BBM to form study groups and work collaboratively on projects. E-books accessed via mobile phone, could also facilitate a more social form of study, with group of 
students collaborating to read, explain and compare one or more texts on the same topic, each working from their individual mobile device (Conejar et al, 2014).

Makoe et al (2012) added that Mobile phones can also be used to enhance learning interaction through weekly self-assessment quizzes, also mobile phone downloadable audio files could also be used to add voice and provide narrative to learning content. They further asserted that the combination of printed study material, mobile phone based self-assessment quizzes and audio will guide a student through a web of learning material while assisting them to pace themselves.

Recent innovations in mobile technologies include access to digital textbooks accessed via ereaders, and the development of mobile applications (apps) and software platforms for accessing educational resources via mobile devices (Conejar et al, 2014). For example, instead of investing in the same textbook set or software solution for an entire classroom, educators could choose from a variety of apps that are tailored to each individual learner, promoting personalized learning, which is expected to characterize formal education in the future. For them, emails and announcements from their lecturers arrive instantaneously 24/7 to their devices. Rather than meeting somewhere at the university campus with their peers to discuss a project, students use chat, SMS, emails and free video telephony software. Communication takes place outside class hours through social media and resources are shared likewise using mobile technology available at their fingertips. This is a technology that allows them to freely record lectures and play them at their own time and location

\section{MOBILE LEARNING PROJECTS}

There are indeed hundreds of mobile phone projects across the globe. Mobile learning is emerging as a new way to reach and connect with students, with different areas of the world adopting this method of teaching and learning at different paces, and for different reasons. (Muckos et al, 2011). Indeed, several mobile phone projects in education and distance education in particular, across the globe starting from the days of Ericsson Education MLearning project, in Dublin Ireland in 2005 (Keegan, 2005), have been implemented according to the specific needs of each country, or the specific problem which the mobile phone projects seek to address: Some few examples of these projects among numerous others cited in literature include: the U.K mobile project for unemployed youths who had urgent need for additional training but refused to attend a training center or college (Keegan, 2005); Blended classroom project in China which pursues anytime, anywhere learning that aims to increase Chinese students' class interactivity using mobile phone (Ally and Tsinakos, 2014); Mobile phone projects that address lack of access to education by disadvantaged groups such as women and girls, scheduled castes and tribes in India (Valk et al, 2010; A mobile phone project that afforded medical students in India access to Tufts University School of Medicine knowledge repository for their clinical training (Ally and Avgustos, 2014); 'Pocket Eijiro' English learning system for mobile phone users which assumes that learners could not make time to learn hence provided learning in their sparetime (Morita, 2010); Mobile phone projects offered to learners who live in deep rural areas with little or no fixed line telecom infrastructure in South Africa; The Nokia MoMath project in South Africa which uses the SMS features on standard mobile phones to provide students with access to mathematics content and support (Ismail et al, 2010); and the use of SMS in Niger to teach functional literacy using local languages (Tsinakos, 2013).

The growth of mobile learning in developing nations has been a direct response to a need for distance education that serves dispersed populations, often characterized by low incomes and the inability to afford expensive PCs and/or Internet access. In contrast, the growth of 
mobile learning in the western world is to complement an already robust use of online distance education. (Muckos et al, 2011).

In Nigeria, mobile learning is still at its infancy more especially with respect to distance education. However a number of studies have demonstrated the potential of mobile learning at higher education in Nigeria. Some of these mobile learning projects include the following:

\section{UNESCO/NOKIA Life+ Project}

In 2013 UNESCO launched a mobile phone project that aims to help teachers improve the English language literacy skills of primary school students in central Nigeria. Teachers selected to participate in the project sign up for a service which sends them richly formatted messages containing education content and pedagogical advice via a platform called NokiaLife+ daily. According to UNESCO website (www.unesco.org), the service, named "English Teacher," is freely accessed on inexpensive handsets common in Nigeria. The project represented one of the first attempts to employ mobile technology to improve the capacity of primary school teachers in West Africa.

UNESCO website further stated that the Project, was a collaboration between UNESCO, Nokia and British Council, with its content developed by the British Council, and tailored specifically for use on mobile devices and for teachers working with large classes in resource-poor schools. The learning content was organized according to themes in sequential modules, and broken across one or two week periods, to teach primary school teachers strategies to encourage leaner independence, cultivate different learning preferences, and reflect on their personal teaching practices. The modules also provided links to other relevant educational resources.

\section{Mobile Learning Platform for Tutorials in Distance Education in the University of Ibadan,} Nigeria

A Learning Platform was created in University of Ibadan for delivering tutorials on mobile devices. The mobile learning platform was officially opened to students on the February 21, 2012 (Utulu \& Alonge, 2012) .The project team collected information and data of students from the Management Information Systems (MIS) unit of the Distance Learning Centre, which were required for purposes of identification, registration and communication. At the beginning of the project, group email accounts were created for the different courses. These email accounts were used to communicate with students such as sending information about their orientation date, lecture commencement dates, etc. In addition, a bulk SMS account was opened in order to reach students, because the SMS is considered one of the fastest, cheapest and most reliable ways to reach the students immediately.

Utulu and Alonge (2012) further reported that at the beginning of the semester, students received a formal orientation on the use of the new instructional delivery formats. Students were divided into groups and were connected to online support referred to as "online tutors." In the first week, students were exposed to the first three modules of each course. A module on the platform is made up of frames, which comprises of a small piece of information a student is exposed to at a particular time. Each frame comes with some practice questions designed to evaluate student's understanding of that unit of instruction, which were either multiple choice type or those requiring writing short answers. The modules also contained chat sessions and forums. Students were encouraged to $\log$ on to chat forums with their mobile phones and make comments on a discussion topic started by the online tutor or by another student. After the learners had successfully gone through the three modules, they were exposed to their first quiz on the mobile platform. 
Educational Advancement Center and Exact Learning Solutions Mobile Learning Initiative at University of Ibadan, Nigeria

Reed (2010) reported an ambitious mobile learning initiative being experimented by tutors and experts through partnerships between the University of Ibadan, Educational Advancement Centre, and a leading Learning Content Management System (LCMS) and Digital Repository (DR) solution provider, eXact Learning Solutions. They developed a system that delivers the required learning materials via mobile phones seamlessly from its LCMS infrastructure.

Reed (2010) further stated that provision of such learning materials via mobile phones will produce a number of benefits for students, teachers and administrators. These benefits include: easy distribution and collation of tests, quizzes and surveys; interaction in real time between the teacher and student, as well as among students, via the forum and chat room; ease with which notifications of events, dead-lines, and timetables are sent to each student; and accessing e-books via mobile phone at some ten to fifteen per cent of the cost of supplying hard copies. The aim of eXact learning solutions was to transform 'standard computerized learning material' into materials that were adapted to be delivered via mobile phone.

KNOWLEDGETAB: A multimedia E-Learning Tablet for Nigerian Senior Secondary Schools KNOWLEDGETAB, one of many recent mobile learning initiatives in Nigeria (which are on the increase especially within the last three years), was first launched as revolutionary interactive learning tool in $\mathbf{2 0 1 3}$ in senior secondary schools across the State of Osun. It was termed 'Opon Imo'. KNOWLEDGETAB is an Android 4.2 tablet computer specially designed initially for Senior Secondary School students but can also be used by tertiary institution students, in Nigeria. The tablet has an e-Library comprising 56 sets of textbooks, a Virtual Classroom containing 51 high quality video tutorials and 15 hours of audio voiceovers, covering 823 textbook chapters and an Assessment Zone, containing over 29,000 simulated past questions covering a period of ten years (HabariNetwork, 2014). According to the website, the Tablet also offers a collection of extra-curricular material, which includes moral instruction, educational games, language lessons and health information. The low-cost, highvalue KNOWLEDGETAB is currently being used by 20,000 students in the State's public education system. Indeed this mobile learning tablet has led to significant savings on the cost of buying textbooks and tutorial question and also allows simplifies the process of updating teaching content by schools and governments without imposing the burden of regular replacement of printed books by students.

KNOWLEDGETAB was also advertised in the Daily Trust (Monday March $10^{\text {th }} 2014, \mathrm{p.13}$ ) as being produced by Softcom Ltd, a Nigerian-based IT solutions firm in collaboration with Phillips Consulting. Advantages of the KNOWLEDGETAB include: its affordability, ruggedness, long-lasting battery and most importantly, all of its content is available in the absence of an Internet connection. (HabariNetwork, 2014).

University of Ibadan/PHEA-TI Project

A mobile project funded by Partnership for Higher Education in Africa-Educational Technology Initiative (PHEA-ETI), is currently being carried out in the University of Ibadan, Nigeria. According to Adedoja et al (2012), the project was developed and designed via the collaborative efforts of various research experts with the aim of providing distance learners access to instructional contents to enable learning at any time and in any place. In the first phase, four pilot courses have been designed on the mobile platform and can be accessed from any mobile device anywhere in the world. This means that distance learners do not have to be physically present in the classroom to access information or submit assignments. The Mobile platform also provides learning activities such as lessons, wikis, quizzes, chats, 
and news forum. The platform also allows Students to have access to course tutors and other students at anytime and anywhere. The courses have been built to fit most of the commonly used internet-enabled mobile phones in Nigeria (Nokia, Samsung, Blackberry, I-phones, HTC, including the less expensive phones, termed China phones (e.g Techno T9). The mobile platform could also be used with tablets such as Samsung Galaxy Tab or I-PAD. Opera mini is the preferred browser for mobile view. The project has now reached implementation stage and is currently being test run in some faculties selected to pilot the project.

\section{Dr Maths on MXit}

MXit is a cell phone instant messaging application which is proprietary software of MXit Lifestyle (Pty) Ltd. based in South Africa. It enables people to easily communicate with each other with textually typed messages which are similar to SMS on mobile phones. One of the primary differences, however, between SMS and MXit is the cost factor. Messages sent via MXit cost approximately one or two cents whereas SMSs could cost upwards to fifty cents depending on contract type. This means that MXit is the South African equivalent of Whats App mobile app. It is extremely quick and easy to get connected with MXit on phones. Just as with Whats App, MXit software is downloaded and registered with via WAP which runs on most modern mobile phones, and then instant communication starts between friends, colleagues and family members (Butgereit, 2014).

According to Butgereit (2014), Math on MXit leverages the fact that teenagers are already using MXit as a medium for communication. For today's teenagers, SMSs are too expensive, and phone calls are too loud. The MXit software can communicate with other instant messaging systems. According to the developers of the system, the Tutorial system called dr.math.help.me was set up as an account at jabber.org. Learners who wanted to take part could merely invite Dr. Math to be one of their contacts and they start asking questions instantly. There are no registration forms to complete, no waiting period, and no costs. Learners use the MXit platform on their mobile phones to ask questions which are routed to a tutor who is online during specified hours to help provide guidance in working out mathematical problems. With this system, the tutors do not do their learners' homework but instead, guide the learners into working out the problems themselves.

\section{Mobile Applications for Education}

Mobile apps are applications developed for small handheld devices, such as mobile phones, smartphones, PDAs and so on. Mobile apps can come preloaded on the handheld device as well as can be downloaded by users from app stores or the Internet. Mobile apps are available on both feature phones and smartphones. The most popular smartphone platforms that support mobile apps are Windows Mobile, Android, Symbian, Java ME and Palm (www.about.com/mobile devices). Mobile apps enable a phone or tablet to do almost anything that the programmers can imagine, within the technical limitations of the device. A number of educational mobile apps can be designed and included on mobile phones. Thus today's rapidly advancing mobile computing technologies together with abundant mobile software applications ("mobile apps") make ubiquitous mobile learning possible with the right educational app developed.

\section{CHALLENGES OF USING MOBILE PHONES IN DISTANCE EDUCATION IN NIGERIA}

The use of mobile phones in learning has a number of drawbacks. UNESCOIITE (2010) described the challenges as: challenge of persuading educators to accept mobile technology as a serious option for education not just a gimmick; small screen size which limits activities on the device; cost of connectivity and cost of device; constant need to keep a mobile device charged; constraints on mobile learning in rural areas due to lack of appropriate technologies; lack of competences required to develop mobile learning opportunities for 
students; human relationships becoming compromised; and increase in stress levels, or feelings of overload by both learners and facilitators. Some other disadvantages of using mobile devices in distance education include the following:

1. The amount of information to be shown on the small screens of mobile devices is limited due to their physical dimensions.

2. It is necessary to charge the batteries of mobile devices regularly. In addition, their batteries have a specific life span.

3. The small keypads of these devices make data input difficult for users.

4. Software developed for computers cannot be directly used in these devices.

5. Opening videos and high-resolution images via the Internet by using mobile devices is sometimes very slow, though this depends on the speed of the wireless Internet connection.

It is noteworthy that with developments in technology, the above constraints will sooner than later be resolved.

\section{CONCLUSION}

The viability of mobile learning in different parts of the world, specifically the developed countries is evident. This evidence, according to Valk et al. (2010) has resulted in the transformation of learning systems from paper-based distance learning to $E$ learning, and then to Mobile learning with emerging learning technologies such as location-aware, context-aware and ubiquitous learning. Thus, the need to explore the possibility of tailoring this learning to the local environment in Nigeria (Traxler, 2011) remains pertinent.

In Nigeria, there is a pervasive evidence of mobile penetration and adoption, as people are increasingly communicating in ways that would have been impossible to imagine only a few years ago. Mobile learning (M-learning) makes learning possible anywhere, anytime, and by various means. Indeed Mobile learning creates new ways of accessing and sharing knowledge and more importantly, results in more flexibility in distance education. But distance education practice in Nigeria has always been dominated by the use of traditional print media, and in some few instances radio. Even the use of television as practiced in other countries such as the China Central Radio and Television University (Perraton, 2007), the Open University United Kingdom (Olugbemi, 2008) among many others, has not taken a firm root in Nigeria. Human beings are by nature very much averse to change especially with respect to adoption of new technology. Nigerians are no exception. When for example, the Federal Minister of Agriculture, Dr. Akinwunmi Adesina, proposed the use of mobile phones to distribute fertilizer, Nigerians were very skeptical and in fact many called the initiative a scam, until it was implemented successfully. According to Agro Nigeria Online (AgroNigeria, 2013), The minister stated that the Electronic Wallet System was introduced to allow small scale farmers receive subsidized electronic vouchers for seeds and fertilizers directly on their mobile phones, in order to cut out rent-seeking middlemen who usually shortchanged farmers.

Mobile phone, as the fastest penetrating technology in human history, has become central to student information activities, playing very important roles in e-learning and e-health (Nwaugwu, 2010; Brown, 2003), and playing a critical role of using bulk SMS by students and facilitating their exchange of information and communication with staff, for example, in the University of South Africa (Nwaugwu, 2010). In Nigeria, mobile technology is fast becoming an educational communication tool as shown by the numerous Mobile learning initiatives cited earlier. According to Wright, Dhanarajan \& Reju (2009), mobile phones are used to teach literacy to some of the $\mathbf{9 . 3}$ million nomads who wander over Nigeria's terrain and along her shoreline. 
However in spite of all the above potentials of mobile devices, in Nigeria, there is general lack of awareness that mobile devices could be used in education and in fact, could move teaching from the classroom to other locations like homes, offices, shops, market place, farmlands, and even on transit, which offers great potential for Distance Education and also the new concept of Flexible and Lifelong Learning (Cook, 2006). However, the above discourse is a pointer to the fact that in the Nigerian context, the use of mobile phones in distance education offers a lot of promise. It could be used to meet the educational needs of: teachers who need further training but could not afford to leave their duties due to dearth of qualified teachers; the nomadic group, such as the Fulani Herdsmen (Aderinoye, 2004); fishermen in the Southern riverine areas (Aderinoye, 2004); women in Purdah in the Northern part of the country; market women in their stalls and shops; girls who drop out of school for economic reasons (Ofoegbu, 2009); unemployed youth who work as apprentices in various trades; itinerant workers and hawkers; our large rural population; and with falling prices it could be extended to the Almajiri group who roam the streets and form a nuisance to the society. All the above mentioned groups need education and training but will not be able to leave their occupations and attend a conventional school. Thus it is apt to state that, mobile learning will afford these deprived group educational opportunity, personal development and enhancement as they manage the challenges of learning, living and working in a diverse, global society.

\section{BIODATA and CONTACT ADDRESSES of AUTHOR(S)}

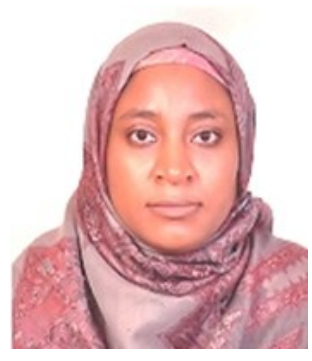

Fatima Shehu KABIR has a Msc. in Computer Science from Birkbeck College, University of London and recently obtained her Ph.D in Instructional Technology from Ahmadu Bello University, Zaria, in November, 2016. Her area of research was the use of mobile devices in Distance Education in Nigeria. Her academic interest areas are open and distance learning, use of social media in education, the future of education, mobile learning and ubiquitous learning. She has written/coauthored about six journal articles, has one paper submitted to a national conference and is presently working on a book chapter.

Fatima Shehu KABIR

ICT Directorate, Kaduna State University, P.M.B 2339, Kaduna, Nigeria

Phone: +2348033121502

E-mail: kfatimashehu@gmail.com or kfatimashehu@kasu.edu.ng

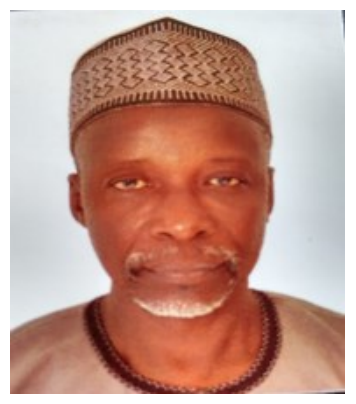

Abdullahi Tukur KADAGE is a professor of Instructional Technology at Usmanu Dan Fodio University, Sokoto. Dr Abdullahi Tukur Kadage gained his Ph.D in Educational Technology in September, 2000. His academic interest areas are: use of multimedia in education, open and distance Education, e-learning and use of internet in education. He has over 5 journal articles published in international indexes, and about 7 papers submitted to international meetings. He participates in Teacher Training projects at both National and International levels. Dr. Tukur is a senior consultant to many international organizations on Distance Education programs. He particularly worked for UNESCO, USAID, and DFID on teacher professional development in Nigeria. 


\author{
Abdullahi Tukur KADAGE \\ Dept. of Curriculum Studies and Educational Technology, \\ Faculty of Education,Usmanu Dan Fodio University, \\ P.M.B 2346, Sokoto, Nigeria \\ Tel: +2348034150062 \\ E-mail: aktukur@gmail.com
}

\title{
REFERENCES
}

Adedoja, G., Adelore, O., Egbokhare, F., \& Oluleye, A. (2013). "Learners' Acceptance of the Use of Mobile Phones to Deliver Tutorials in a Distance Learning Context: A Case Study at the University of Ibadan. The African Journal of Information system.

Adedoja, G., Botha, A., Ogunleye, O.S. (2012). The Future of Mobile Learning in the Nigerian Education System. IST-Africa 2012 Conference Proceedings. Paul Cunningham and Miriam Cunningham (Eds) IIMC International Information Management Corporation, 2012.

Aderinoye, R., \& Ojokheta, K. (2004). Open-Distance Education as a Mechanism for Sustainable Development: Reflections on the Nigerian Experience. International Review of Research in Open and Distance Learning, 5(1).

AgroNigeria, (2013). Africa embraces Nigeria's e-wallet System. Retrieved from http://www.Agronigeria.com.ng/2013/10/21/Africa-embraces-Nigeria's-e-walletsystem/

Al-Fahad, F.N. (2009). Students' Attitudes and Perceptions towards the Effectiveness of Mobile Learning in King Saud University, The Turkish Online Journal of Educational Technology, $8(2)$.

Ally, M., Tsinakos, A. (2014). Increasing Access Through Mobile Learning. Vancouver: Common Wealth of Learning.

Bradford, D. J. (2010). Emerging And Disruptive Technologies For Education: An Analysis Of Planning, Implementation, And Diffusion In Florida'S Eleven State University System Institutions. Unpublished PhD Dissertation: University of Central florida.

Brown, T. H. (2003). The Role of MLearning in the future of ELearning in Africa. 21st ICDE World Conference, Hong Kong. Hong Kong.

Butgereit, L. (2014) Math on MXit: Using MXit as a Medium for Mathematics Education. Meraka, South Africa.

Conejar, R. J., Haeng-Kon, K. (2014). International Journal of Software Engineering and Its Applications Vol.8, No.8. (pp. 193-200) http://dx.doi.org/10.14257/ijseia.2014.8.8,18

Cook, A. V. (2006). Experience of Adult Learners in Distance Education of SMS Technology as a Learnng support Tool. Pretoria: University of Pretoria.

HabariNetwork. (2014). Softom launches knowledgetab for Nigerian Students, Retrieved June 22, 2015, from http: // www.thehabarinetwork.com/softom-launches-knowledgetab-fornigerian-students.

Handan,B., MacNish, J., Petocz, P. (2013). Adopting Mobile Learning in Tertiary Environments: Instructional, Curricular and Organizational Matters. Education Sciences, 3, 359-374; doi: $10.3390 /$ educsci3040359 
Ismail, I., Gunasegaran, T., Koh, P.P. \& Idrus, R.M. (2010). Satisfaction of distance learners towards mobile learning in the Universiti Sains Malaysia. Malaysian Journal of Educational Technology, 10(2), 47-54.

Kadage, A. (2013). Quality and Equality Questions in Technology Mediated Distance Learning. Journal of Educational Media and Technology, Volume 17, Number 1, 17(1).

Keegan, D. (2005). The Incorporation of Mobile Learning into Mainstream Education and Training. mLearn2005: 4th World conference on mLearning. Cape Town: mLearn2005.

Kwache, P. (2007). The Imperatives of Information and Communication Technology for Distance Education. MERLOT Journal of Online Learning and Teaching, 3(4).

Makoe, M. (2012). The Pedagogy of Mobile Learning in Supporting Distance Learners. UNISA. Retrieved June 20, 2015 from http://umkn-dsp01.unisa.ac.za/ handle/10500/8797

Morita, M. (2010, 08). The Mobile-based Learning (MBL) in Japan. Retrieved June 20, 2015, fromhttp://www.computer.org/csdl/proceedings/c5/2003/1975/00/19750128.pdf

Muckos, L., Dawson, H., Edel-Malizia, S., Shaffer-Swaggerty, D. (2011). The Impact of Mobile Access on Motivation: Distance Education Student Perceptions. World Campus Learning Design. Penn state.

Nwaugwu, W., Odetumibi, S. (2010). Factors Influencing The Adoption of Mobile Telephony by Students at The University of Ibadan, Nigeria. Turkish Online Journal of Distance Education, 12(4).

Ofoegbu, I. (2010). Female Access to Basic Education: A case for Open and Distance Learning. Edo Journal of Counselling, 7(1).

Ofulue, C. (2011). Survey of Barriers Affecting The Use of Information Communication Technologies (Icts) Among Distance Learners: A Case Study of Nigeria.Turkish Online Journal of Distance Education, 12(3).

Olakulehin, F. (2010). Open Flexible Lifelong Learning As A Catalyst For Sustainable Development In Sub-Saharan Africa. Turkish Online Journal of Distance Education, 11(4).

Ololube, N. P., Ubogu, A. E., \& Ossai, A. G. (2006). ICT and Distance Education in Nigeria: A Review of Literature and Accounts. 2nd International Open and Distance Learning Symposium (pp. 643-655). Eskisehir: IODL.

Olugbemi, M. O. (2008). Development And Implementation Of A Mathematical Model Of Distance Education. Ahmadu Bello University. Zaria: Ahmadu Bello University.

Osang, F (2012). Internet Access in Nigeria: Perception of National Open University of Nigeria (Noun) Students. International Journal of Emerging Technology and Advanced Engineering. 2(10).

Osang, F.B, Tsuma, C, Ngole, J. (2013). Prospects and Challenges of Mobile Learning Implementation in Nigeria: Case Study National Open University of Nigeria (Noun). "International Conference on ICT for Africa 2013", February 20 -23, Harare, Zimbabwe.

Perraton, H. (2007). Open and Distance Learning in the Developing World (Second Edition ed.). London: RoutledgeFalmer. 
Peters, K. (2007). M-Learning: Positioning educators for a mobile, connected future. Internationall Review of Resesarch in Open and Distance Learning, 8(2).

Reed, B. I. (2010, December 3). Nigerian University of Ibadan Educational Advancement Center and Exact Learning Solutions Start African Mobile Learning Initiative. Retrieved February 5, 2015, from http: // www.personneltoday.com/ hr/nigerian-university-of-ibadaneducational-advancement-center-and-exact-learning-solutions-start-african-mobilelearning-initiative/

Suki, N. M., \& Suki, N. M. (2009). Are lecturers' ready for usage of mobile technology for teaching? World Academy of Science, Engineering and Technology, 17(3).

Traxler, J. (2007). Defining, Discussing, and Evaluating Mobile Learning:The Moving Finger writes And Having Written. Internationall Review of Resesarch in Open and Distance Learning, $\boldsymbol{8 ( 2 ) \text { . }}$

Tsinakos, A. (2013). Global Mobile Learning Implementation and Trends. Beijing: China Central Radio \& TV University Press.

UNESCO. (2002). Open and Distance Learning: Trends, Policies and Strategy Considerations, Paris: UNESCO, Division of Higher Education.

UNESCO.IITE (2010). Mobile learning for quality education and social inclusion: Policy Brief. Moscow, Russian Federation.

Utulu, S. C., \& Alonge, A. (2012). Use of mobile phones for project based learning by undergraduate students of Nigerian private universities. International Journal of Education and Development using Information and Communication Technology, 8(1), 415.

Valk, J.-H., Rashid, A. T., \& Elder, L. (2010). Using Mobile Phones to Improve Educational Outcomes: An Analysis of Evidence from Asia. Institute of Research in Open and Distance Learning, 12(2).

Wang, S-L., Chen, C-C, \& Zhang, Z, (2015). A context-aware Knowledge Map to Support Ubiquitous Learning Activities in u-Botannical Museum. Australian Journal of Educational Technology 31(4), 470-485.

WorldBank. (2013). Nigerian Education Sector Overhaul. Retrieved February 20, 2014, from http: / / www.worldbank.org/en/results/2013/02/04/education-sector-overhaul.

Wright, C. R., Dhanarajan, G., \& Reju, S. A. (2009, feb). Recurring Issues Encountered by Distance Educators in Developing and Emerging Nations,. International Review of Research on Open and Distance Learning, 10(1).

Yusuf, M. O. (2006, January). Problems and Prospects of Distance Education in Nigeria. Turkish Online Journal of Distance Education, $\pi(1)$. 